\title{
IMPLEMENTASI PEMBELAJARAN ENERGI DAN PERUBAHANNYA MELALUI PENDEKATAN SAINTEFIK DENGAN MODEL PEMBELAJARAN INQUIRY LEARNING MATA PELAJARAN IPA SISWA KELAS IV SD NEGERI KWAYUHAN
}

\author{
PARJINEM \\ SD Negeri Kwayuhan \\ e-mail: parjinem72@gmail.com
}

\begin{abstract}
ABSTRAK
Rendahnya hasil belajar IPA siswa kelas IV, menuntut guru untuk melakukan inovasi. Salah satunya dengan menerapkan Pendekatan Saintefik dengan model Inquiry Learning pada implementasi Pembelajaran Energi dan Perbahannya pada Siswa Kelas IV SD Negeri Kwayuhan. Proses pembelajaran tematik yang dilakukan dengan menerapkan model pembelajaran Inquiry Learning berlangsung aktif. Aktifitas pembelajaran yang dirancang sesuai sintak Inquiry Learning megharuskan siswa aktif selama proses pembelajaran. Pembelajaran tematik yang dilakukan dengan menerapkan model pembelajaran Inquiry Learning meningkatkan kemampuan siswa dalam melakukan transfer knowledge, meningkatkan kemampuan siswa untuk berpikir kritis. Hal ini dapat dilihat dari tingkat partisipasi siswa untuk bertanya dan menanggapai topik yang dibahas dalam pembelajaran. Penerapan model pembelajaran Inquiry Learning juga meningkatkan kemampuan siswa dalam memecahkan masalah (problem solving). Dengan menerapkan Inquiry Learning, siswa tak hanya belajar dari teks tulis, tetapi juga dari gambar-gambar serta diberi kesempatan terbuka untuk mencari data, materi dari sumber lainnya. Penerapan model pembelajaran Inkuiry learning juga meningkatkan hasil belajar meningkat. Hal ini dibuktikan dari peningkatan ketuntasan klasikal dan rata-rata hasil belajar siswa. Ketuntasan klasikal siswa, meningkat sebesar $35,7 \%$, yaitu dari $50 \%$ menjadi $85,7 \%$. Sedangkan rata-rata hasil belajar siswa meningkat sebesar 7,2 poin yaitu dari 71,8 menjadi 79 .
\end{abstract}

Kata Kunci: Pendekatan Saintefik, Inquiry Learning

\section{PENDAHULUAN}

Pembelajaran tematik terpadu di SD sesuai dengan tuntutan Kurikulum 2013 merupakan pendekatanpembelajaran yang mengintegrasikan beberapa muatan pelajaran dalam satupembelajaran. Beberapa muatan, misalnya Bahasa Indonesia, IPA, dan IPS disatukan dalam tema yang sama kemudian disajikan dalam satu pembelajaran utuh yang saling berkaitan (Maulana Arafat Lubis, dalam buku Pembelajaran Tematik di SD/MI).

Dalam praktik pembelajaran Kurikulum 2013 yang penulis lakukan selama ini, penulis menggunakan buku siswa dan buku guru. Penulis meyakini bahwa buku tersebut sudah sesuai dan baik digunakan di kelas karena diterbitkan oleh Kementerian Pendidikan dan Kebudayaan. Ternyata, dalam praktiknya, penulis mengalami beberapa kesulitan seperti materi dan tugas tidak sesuai dengan latar belakang siswa. Selain itu, penulis masih berfokus pada penguasaan pengetahuan kognitif yang lebih mementingkan hafalan materi. Dengan demikian proses berpikir siswa masih dalam level C1 (mengingat), memahami (C2), dan C3 (aplikasi). Guru hampir tidak pernah melaksanakan pembelajaran yang berorientasi pada keterampilan berpikir tingkat tinggi (higher order thinking skills/HOTS). Penulis juga jarang menggunakan media pembelajaran. Dampaknya, suasana pembelajaran di kelas kaku dan anak-anak tampak tidak ceria.

Berdasarkan hasil wawancara dengan beberapa siswa diperoleh informasi bahwa (a) siswa malas mengikuti pembelajaran yang banyak dilakukan guru dengan cara ceramah (b) 


\section{SCIENCE : Jurnal Inovasi Pendidikan Matematika dan IPA Vol. 1 No. 2 Agustus 2021 e-ISSN : 2797-1031 | p-ISSN : 2797-0744}

selain ceramah, metode yang selalu dilakukan guru adalah penugasan. Sebagian siswa mengaku jenuh dengan tugas-tugas yang hanya bersifat teoritis. Tinggal menyalin dari buku teks.

Untuk menghadapi era Revolusi Industri 4.0, siswa harus dibekali keterampilan berpikir tingkat tinggi (higher order thinking skills). Salah satu model pembelajaran yang berorientasi pada HOTS dan disarankan dalam implementasi Kurikulum 2013 adalah Model pembelajaran Inquiry Learning. Sebuah model pembelajaran yang dirancang membawa peserta didik dalam proses penelitian melalui penyelidikan dan penjelasan dalam setting waktu yang singkat (SE Arlita, 2020).

Setelah melaksanakan pembelajaran tematik terpadu dengan model Inquiry Learning, penulis menemukan bahwa proses dan hasil belajar siswa meningkat. Lebih bagus dibandingkan pembelajaran sebelumnya. Ketika model Inquiry Learning ini diterapkan pada kelas IV yang lain ternyata proses dan hasil belajar siswasamabaiknya. Praktik pembelajaran Inquiry Learningyang berhasil baik ini penulis simpulkan sebagai sebuah best practice (praktik baik) pembelajaran berorientasi HOTS dengan model Inquiry Learning.

Berdasarkan latar belakang di atas, maka rumusan masalah yang akan dikaji adalah, "Apakah Implementasi Pembelajaran Energi Matahari dan Perubahannya dapat dilakukan dengan pendekatan saintefik dan metodeInquiry Learningmata pelajaran IPA kelas 4 Tahun Pelajaran 2019/2020". Adapun tujuan dari penulisan best practice ini adalah untuk mendeskripsikan praktik baik penulis dalam menerapkan pembelajaran berorientasi higher order thiking skills (HOTS).Secara umum dapat meningkatkan profesionalisme Pendidik dan TenagaKependidikan, dansecara khusus misalnya dapat meningkatkan kualitas pembelajaran, meningkatkan kemampuan siswa, meningkatkan aktivitas belajar siswa baik secara individual maupun secara kelompok, meningkatkan kedisiplinan siswa, meningkatkan kesadaran hidup bersih, dan kesadaran cinta lingkungan.Manfaat penulisan praktik baikini adalah meningkatkan kompetensi siswa dalam pembelajaran tematik integrative yang berorientasi HOTS.

\section{METODE PELAKSANAAN}

Penulis melakukan penelitian menggunakan pengalaman terbaiknya dalam mengajar dikelasnya. Penulisan best practice ini dilakukan oleh guru pada saat melaksanakan kegiatan pembelajaran dengan metode pemecahan masalah yang berisi paparan teori atau pengalaman yang dijadikan rujukan dalam menyelesaikan masalah, meggunakan bahan/materi pembelajaran tematik/gabungan Kompetensi Dasar Bahasa Indonesia, IPA, dan IPS.

Bahan yang digunakan dalam praktik baik pembelajaran ini adalah materi kelas IV untuk tema Selalu berhemat Energi subtema Sumber Energi dengan materi pokok Manfaat Energi dan Perubahannya merupakan pembelajaran tematik gabungan KD Bahasa Indonesia, IPA, dan IPS. Kompetensi Dasar 3.2 Bahasa Indonesia,mencermati keterhubungan antargagasan yang didapat dari teks lisan, tulis, atau visual. Kompetensi Dasar 3.1 IPS, mengidentifikasi karakteristik ruang dan pemanfaatan sumber daya alam untuk kesejahteraan masyarakat dari tingkat kota/kabupatensampai tingkat provinsi. Kompetensi Dasar 3.5 IPA, mengidentifikasi berbagai sumber energi, perubahan bentuk energi, dan sumber energi alternatif (angin, air, matahari, panas bumi, bahan bakar organik, dan nuklir) dalam kehidupan sehari-hari.Pemetaan Kompetensi Dasar (KD) dilakukan untuk memasangkan KD yang akan dilaksanakan dalam pembelajaran tematik. Penulis memilih tema yang sesuai dan merumuskan indikator pencapaian kompetensi dari KD muatan pelajaran Bahasa Indonesia, IPA, dan IPS.Hasil analisis target kompetensi Bahasa Indonesia 3.2.1 adalah mengidentifikasi informasi dari teks visual yang diamati, IPS 3.1.1 adalah mengidentifikasi sumber daya alam dan pemanfaatannya, IPA 3.5.1 adalah menjelaskan manfaat energi matahari dalam kehidupan sehari-hari.

Penulis menentukan model pembelajaran Inquiry Learning dan merencanakan sintaksintaknya. Adapun Sintak model Inquiry Learning meliputi: 1) Orientasi masalah, 2) Merumuskan masalah, 3) Merumuskan hipotesis, 4) Mengumpulkan data, 5) Menguji hipotesis, 
dan 6) Menarik kesimpulan. Selanjutnya penulis menyusun perangkat pembelajaran berupa:Rencana Pelaksanaan Pembelajaran (RPP), bahan ajar, Lembar Kerja Siswa (LKS), dan instrumen penilaian. Rencana Pelaksanaan Pembelajaran (RPP) disusun dengan mengintegrasikan kegiatan literasi, penguatan pendidikan karakter (PPK), dan kecakapan abad 21.Sasaran pelaksanaan best practice ini adalah siswa kelas IV semester 1 di SD Negeri Kwayuhan sebanyak 14 orang dengan nilai rata-rata kelas 71,8 dan ketuntasan kelas dengan KKM 71 mencapai $50 \%$.

\section{HASIL DAN PEMBAHASAN}

Hasil

Dalam kurikulum 2013 pendekatan yang diterapkan adalah pendekatan saintifik (scientific approach) atau pendekatan berbasis keilmuan, dimana dalam kegiatan inti pembelajaran dengan menggunakan pendekatan ini peserta didik diharapkan mampu melaksanakan 5 (lima) tahapan kegiatan. Lima kegiatan inti dalam pembelajaran dengan pendekatan saintifik adalah kegiatan mengamati, menanya, megumpulkan informasi, menalar, dan mengkomunikasikan. Pendekatan saintifik dilaksanakan dengan modus pembelajaran langsung dan tidak langsung. Dalam kurikulum 2013 sebagai penerapan dari pendekatan saintifik, maka dibentuklah model pembelajaran yang dapat dipilih oleh guru yang nantinya akan disesuaikan dengan materi pelajaran. Model pembelajaran dalam kurikulum ini merupakan kerangka konseptual dan operasional pembelajaran yang memiliki nama, ciri, urutan, logis, pengaturan, dan budaya. Model pembelajaran dalam kurikulum 2013 antara lain discovery learning, project-based learning, problem-based learning, dan inquiry learning (Permendikbud No.103/2014).

Proses pembelajaran tematik yang dilakukan dengan menerapkan model pembelajaran Inquiry Learning berlangsung aktif. Siswa menjadi lebih aktif merespon pertanyaan dari guru, termasuk mengajukan pertanyaan pada guru maupun temannya. Aktifitas pembelajaran yang dirancang sesuai sintak Inquiry Learning megharuskan siswa aktif selama proses pembelajaran.

Pembelajaran tematik yang dilakukan dengan menerapkan model pembelajaran Inquiry Learning meningkatkan kemampuan siswa dalam melakukan transfer knowledge. Setelah membaca, meringkas, dan mendiskusikan teks eksplanasi tentang Manfaat Energi dan Perubahannya, siswa tidak hanya memahami konsep teks eksplanasi (pengetahuan konseptual) dan bagaimana membuat ringkasan yang benar (pengetahuan prosedural), tetapi juga memahami konsep manfaat energi dan perubahannya. Pemahaman ini menjadi dasar siswa dalam mempelajari materi IPS tentang sumber daya alam dan pemanfaatannya. Pemahaman tentang konsep Manfaat Energi dan Perubahannya membantu siswa dalam menganalisis.

Penerapan model pembelajaran Inquiry Learning meningkatkan kemampuan siswa untuk berpikir kritis. Hal ini dapat dilihat dari tingkat partisipasi siswa untuk bertanya dan menanggapai topik yang dibahas dalam pembelajaran. Dalam pembelajaran sebelumnya yang dilakukan penulis tanpa berorientasi HOTS suasana kelas cenderung sepi dan serius. Siswa cenderung bekerja sendiri-sendiri untuk berlomba menyelesaikan tugas yang diberikan guru. Fokus guru adalah bagaimana siswa dapat menyelesikan soal yang disajikan; kurang peduli pada proses berpikir siswa. Tak hanya itu, materi pembelajaran yang selama ini selalu disajikan dengan pola deduktif (diawali dengan ceramah teori tentang materi yang dipelajari, pemberian tugas, dan pembahasan), membuat siswa cenderung menghapalkan teori. Pengetahuan yang diperoleh siswa adalah apa yang diajarkan oleh guru. Berbeda kondisinya dengan praktik baik pembelajaran tematik berorientasi HOTS dengan menerapkan Inquiry Learning ini. Dalam pembelajaran ini pemahaman siswa tentang konsep teks eksplanasi, perubahan sosial budaya, dan cara mahluk hidup menyesuaikan diri benar-benar dibangun oleh siswa melalui pengamatan dan diskusi yang menuntut kemampuan siswa untuk berpikir kritis.

Penerapan model pembelajaran Inquiry Learning juga meningkatkan kemampuan siswa dalam memecahkan masalah (problem solving). Inquiry Learning yang diterapkan dengan menyajikan teks tulis dan gambar-gambar berisi permasalahan kontekstual mampu mendorong 
siswa merumuskan pemecahan masalah. Sebelum menerapkan Inquiry Learning, penulis melaksanakan pembelajaran sesuai dengan buku guru dan buku siswa. Meskipun permasalahan yang disajikan dalam buku teks kadang kala kurang sesuai dengan kehidupan sehari-hari siswa, tetap saja penulis gunakan. Jenis teks yang digunakan juga hanya pada teks tulis dari buku teks. Dengan menerapkan Inquiry Learning, siswa tak hanya belajar dari teks tulis, tetapi juga dari gambar-gambar serta diberi kesempatan terbuka untuk mencari data, materi dari sumber lainnya.

Berdasarkan hasil Belajar siswa yang telah dilaksanakan, dapat diketahui hasil belajar siswa pada Tabel 1 sebagai berikut.

Tabel 1. Hasil Belajar Siswa Kelas 4 SD N Kwayuhan

\begin{tabular}{cccc}
\hline No & Kode Anak & Nilai & Keterangan \\
\hline 1 & V001 & 76 & Tuntas \\
2 & V002 & 100 & Tuntas \\
3 & V003 & 100 & Tuntas \\
4 & V004 & 73 & Tuntas \\
5 & V005 & 65 & Tidak tuntas \\
6 & V006 & 67 & Tidak tuntas \\
7 & V007 & 76 & Tuntas \\
8 & V008 & 73 & Tuntas \\
9 & V009 & 75 & Tuntas \\
10 & V010 & 74 & Tuntas \\
11 & V011 & 100 & Tuntas \\
12 & V012 & 83 & Tuntas \\
13 & V013 & 73 & Tuntas \\
14 & V014 & 71 & Tuntas \\
& Jumlah & 1106 & \\
\hline
\end{tabular}

Berdasarkan Tabel 1, maka dapat dihitung ketuntasan klasikal dan rata-rata siswa sebagai berikut.

1. Ketuntasan klasikal

Untuk menghitung ketuntasan klasikal siswa, maka dapat menggunakan rumus sebagai berikut.

$$
\begin{aligned}
K K & =\frac{\text { Jumlahsiswayangtuntas }}{\text { Jumlahseluruhsiswa }} \times 100 \% \\
& =\frac{12}{14} \times 100 \% \\
& =85,7 \%
\end{aligned}
$$

Sehingga diperoleh ketuntasan klasikal siswa sebesar 85,7\%, yang artinya ketuntasan klasikal siswa meningkat sebesar 35,7 \% dari ketuntasan awal siswa.

2. Rata-rata

Berdasarkan tabel di atas, maka dapat dihitung rata-rata siswa menggunakan rumus berikut.

$$
\begin{aligned}
M & =\frac{\sum f x}{N} \\
& =\frac{1106}{14} \\
& =79
\end{aligned}
$$


Dengan demikian dapat diketahui rata-rata siswa sebesar 79. Rata-rata siswa meningkat sebesar 7,2 poin dari rata-rata awal. Peningkatan ketuntasan klasikal dan rata-rata siswa menunjukkan bahwa penerapan Pendekatan Saintifik dengan model Pembelajaran Inquiry Learning sangat efektif dalam meningkatkan hasil belajar siswa. Untuk lebih jelas mengenai peningkatan ketuntasan klasikal dan rata-rata siswa, dapat dilihat pada diagram Gambar 1 berikut.

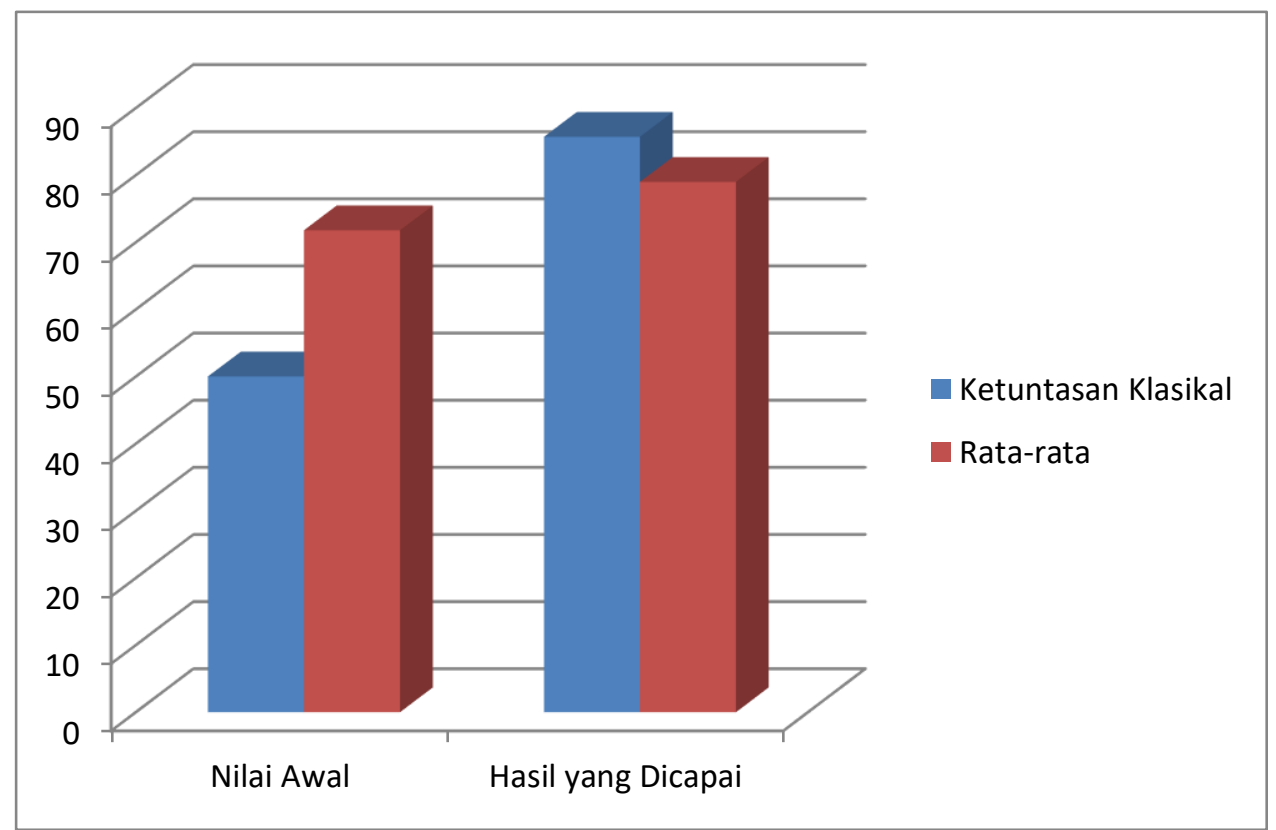

Gambar 1. Diagram Peningkatan Ketuntasan Klasikal dan Rata-rata Siswa

\section{Pembahasan}

\section{Pendekatan Saintifik dan Kurikuklum 2013}

Menurut Aswin Banawi (2019), pendekatan saintifik merupakan kerangka ilmiah pembelajaran yang diusung oleh kurikulum 2013. Langkah-langkah pada pendekatan saintifik merupakan bentuk adaptasi dari langkah-langkah ilmiah pada sains. Proses pembelajaran dapat dipadankan dengan suatu proses ilmiah, karenanya kurikulum 2013 mengamatkan esensi pendekatan saintifik dalam pembelajarannya. Berdasarkan Wayan (2019), pendekatan saintifik diyakini sebagai titian emas perkembangan dan pengembangan sikap, keterampilan, dan pengetahuan peserta didik. Dalam pendekatan atau proses kerja yang memenuhi kriteria ilmiah, para ilmuan lebih mengedepankan penalaran induktif (inductive reasoning) dibandingkan dengan penalaran deduktif (deductive reasoning). Penalaran deduktif melihat fenomena umum untuk kemudian menarik simpulan yang spesifik. Sebaliknya, penalaran induktif memandang fenomena atau situasi spesifik untuk kemudian menarik simpulan secara keseluruhan. Sejatinya, penalaran induktif menempatkan bukti-bukti spesifik ke dalam relasi ide yang lebih luas. Metode ilmiah umumnya menempatkan fenomena unik dengan kajian spesifik dan detail untuk kemudian merumuskan simpulan umum. Metode ilmiah merujuk pada teknik-teknik investigasi atas suatu atau beberapa fenomena atau gejala, memperoleh pengetahuan baru, atau mengoreksi dan memadukan pengetahuan sebelumnya.

Menurut Permendikbud Nomor 103 Tahun 2014, pendekatan saintifik/pendekatan berbasis proses keilmuan dilaksanakan dengan menggunakan modus pembelajaran langsung atau tidak langsung sebagai landasan dalam menerapkan berbagai strategi dan model pembelajaran sesuai dengan Kompetensi Dasar yang ingin dicapai. Kelima kegiatan pokok 5M (mengamati, menanya, mengumpulkan informasi, menalar atau mengasosiasi, 


\section{SCIENCE : Jurnal Inovasi Pendidikan Matematika dan IPA Vol. 1 No. 2 Agustus 2021 e-ISSN : 2797-1031 | p-ISSN : 2797-0744}

mengkomunikasikan) di atas adalah aktivitas minimal, guru dapat mengembangkannya sesuai dengan kebutuhan.

Pendekatan saintifik (Daryanto, 2014) merupakan salah satu pendekatan pembelajaran yang diarahkan pada penerapan metode ilmiah. Sebuah metode yang merupakan aktivitas pengumpulan data melalui observasi atau eksperimen, mengolah informasi atau data, menganalisis, kemudian memformulasi, dan menguji hipotesis. Pendekatan saintifik dalam kegiatan pembelajaran bukan hanya mengembangkan kompetensi siswa untuk melakukan kegiatan observasi atau eksperimen saja, tetapi juga mengembangkan keterampilan berpikir kritis dan kreatif siswa dalam berinovasi atau berkarya. Pendekatan saintifik dapat mengembangkan sikap, pengetahuan dan keterampilan siswa

\section{Model Inquiry}

Proses pembelajaran tematik yang dilakukan dengan menerapkan model pembelajaran Inquiry menurut Akhmad Sudrajad (2011),pembelajaran Inquiry merupakan kegiatan pembelajaran yang melibatkan secara maksimal seluruh kemampuan siswa untuk mencari dan menyelidiki sesuatu (benda, manusia atau peristiwa) secara sistematis, kritis, logis, dan analitis sehingga mereka dapat merumuskan sendiri penemuannya dengan penuh percaya diri.

Al-Tabani (2014: 147) inkuiri merupakan bagian inti dari kegiatan pembelajaran berbasis kontekstual. Pengetahuan dan keterampilan yang diperoleh siswa diharapkan bukan hasil mengingat seperangkat fakta, melainkan hasil dari menemukan sendiri.

Al-Tabani (2014: 80) menjelaskan ciri-ciri pembelajaran inkuiri yaitu: 1) pembelajaran inkuiri menekankan kepada aktivitas siswa secara maksimal untuk mencari dan menemukan, 2) seluruh aktivitas yang dilakukan siswa diarahkan untuk mencri dan menemukan jawaban sendiri dari sesuatu yang dipertanyakan, sehingga diharapkan untuk dapat menumbuhkan sikap percaya diri, 3) tujuan dari pembelajaran inkuiri yaitu mengembangkan kemampuan berfikir secara sistematis, logis, dan kritis, atau mengembangkan kemampuan intelektual sebagai bagian dari proses mental.

Al-Tabani (2014: 82), mengemukakan bahwa langkah-langkah kegiatan inkuiri adalah sebagai berikut, 1) Merumuskan masalah, 2) Mengamati atau melakukan observasi, 3) Menganalisis dan menyajikan hasil dalam tulisan, gambar, laporan, bagan, tabel, dan karya lainnya, dan 4) Mengkomunikasikan atau mnyajikan hasil karya pada pembaca, teman sekelas, guru, audiens yang lainnya. Adapun sintak model pembelajarn Inquiry Learning, sebagai berikut: 1) Orientasi masalah,tahap ini merupakan tahap dimana siswa pertama kali untuk diperkenalkan terhadap masyarakat, 2) Merumuskan masalah, perumusan permasalahan ini melingkupi tantangan apa yang harus dicari jawabannya terkait permasalahan yang diangkat, 3) Merumuskan Hipotesis, guru meminta jawaban sementara atau dugaan sementara (hipotesis) dari siswa terkait permasalahan yang dibahas bersama, 4) Tahap pengumpulan data,setelah siswa memiliki dugaan sementara terhadap penyebab permasalahan maka langkah selanjutnya siswa diminta untuk mencari data pendukung sebagai proses pembuktian hipotesis tersebut,5) Menguji hipotesis,dari data yang terkumpul, selanjutnya digunakan untuk melakukan pengujian terhadap hipotesis tadi sehingga akan dapat dibuktikan apakah hipotesis tersebut benar atau salah, dan 6)Menarik kesimpulan, kesimpulan diperoleh setelah seluruh langkah pembuktian telah dilaksanakan.Kesimpulan yang telah didapat bisa selanjutnya dikomunikasikan kepada siswa yang lainnya melalui presentasi.

Dalam Peraturan Menteri Pendidikan dan Kebudayaan Nomor 22 Tahun 2016 tentang Standar Proses Pendidikan Dasar dan Menengah (Permendikbud No. 22/2016 tentang standar proses dikdasmen) dikatakan bahwa pembelajaran inquiry disebut bersama dengan discovery. Penemuan melalui proses berpikir secara sistematis. Pengetahuaan bukan sekedar sekumpulan fakta hasil dari mengingat, akan tetapi hasil dari proses menemukan atau mengkonstruksi. Dengan kata lain, pembelajaran merupakan proses fasilitasi kegiatan penemuan (inquiry) agar peserta didik memperoleh pengetahuan dan keterampilan melalui penemuannya sendiri (discovery). Menurut Sani (2015) inkuiri dapat dijadikan sebagai pendekatan pembelajaran, 
strategi pembelajaran, atau metode pembelajaran. Pembelajaran diskoveri dapat dipadukan dengan inkuiri denganmengajukan hipotesis tentang sebuah percobaan. Menurut Herdian (2010) metode pembelajaran discovery (penemuan) adalah metode mengajar yang mengatur pengajaran sedemikian rupa sehingga anak memperoleh pengetahuan yang sebelumnya belum diketahuinya itu tidak melalui pemberitahuan, sebagian atau seluruhnya ditemukan sendiri. Sintaks Pembelajaran Diskoveri/Inkuiri sebagai berikut: 1) dihadapkan dengan permasalahan, 2) pengumpulan data untuk verifikasi, 3) pengumpulan data dalam eksperimen, 4) organisasi, perumusan, dan penjelasan, dan 5) menganalisis proses inkuiri (Sani, 2015: 97). Selanjutnya sintaks tersebut dihubungkan dengan unsur dalam pendekatan saintifik. Hubungan 5M dengan Pembelajaran Diskoveri/Inkuiri tampak pada Tabel 2 berikut.

\section{Tabel 2. Hubungan 5M dengan Sintaks Pembelajaran Diskoveri/Inkuiri}

\begin{tabular}{|c|c|c|}
\hline Kegiatan Pokok 5M & Sintak & Deskripsi \\
\hline Mengamati & Merumuskan pertanyaan & $\begin{array}{l}\text { Memberi stimulus; bacaan, atau } \\
\text { mengamati gambar, atau situasi, } \\
\text { sesuai } \quad \text { dengan } \\
\text { pembelajaran/topik/tema. Materi } \\
\text { pembelajar sepanjang hayat, ingin } \\
\text { tahu }\end{array}$ \\
\hline Menanya & Merencanakan & $\begin{array}{l}\text { Mengidentifikasi masalah; } \\
\text { mengajukan pertanyaan, menemukan } \\
\text { permasalahan menanya, mencari } \\
\text { informasi, dan merumuskan masalah } \\
\text { dan merencanakan prosedur atau } \\
\text { langkah-langkah dan pengumpulan } \\
\text { dan analisis data, kerja kera }\end{array}$ \\
\hline $\begin{array}{l}\text { Mengumpulkan } \\
\text { informasi }\end{array}$ & $\begin{array}{l}\text { Mengumpulkkan } \\
\text { menganalisis data }\end{array}$ & $\begin{array}{l}\text { Kegiatan mengumpulkan informasi, } \\
\text { fakta, maupun data, dilanjutkan } \\
\text { dengan kegiatan menganalisis data, } \\
\text { mengajukan kemungkinan jawaban. } \\
\text { Melatih ketelitian, akurasi, dan } \\
\text { kejujuran, kerja keras }\end{array}$ \\
\hline Mengasoisasi & Menarik simpulan & $\begin{array}{l}\text { Memverifikasi; mengecek kebenaran } \\
\text { atau keabsahan hasil pengolahan data, } \\
\text { mencari sumber yang relevan baik } \\
\text { dari buku atau media, } \\
\text { mengasosiasikannya menjadi suatu } \\
\text { kesimpulan. Cinta kebenaran }\end{array}$ \\
\hline Mengkomunikasikan & $\begin{array}{l}\text { Aplikasi dan tindak } \\
\text { lanjut }\end{array}$ & $\begin{array}{l}\text { Menyajikan hasil temuan, } \\
\text { merumuskan kesimpulan berdasarkan } \\
\text { data yang diolah, dan mengeksplorasi } \\
\text { pertanyaan-pertanyaan an } \\
\text { permasalahan lanjutan untuk dicari } \\
\text { jawabnya. Menjadi pembelajar } \\
\text { sepanjang hayat, ingin tahu }\end{array}$ \\
\hline
\end{tabular}

Ruli Diyan Aprianoto (2015) Penerapan Model Inkuiri untuk meningkatkan Pembelajaran IPA Kelas V Semester II Pada Materi Magnet SDN Bandungrejosari, dikemukakan bahwa pelaksanaan pembelajaran IPA dengan model inkuiri menjadi efektif. Aktivitas Guru mengajar pada siklus I $87 \%$ dan siklus II 95\%, sedangkan aktivitas selama pembelajaran menggunakan model Inkuiri mengalami meningkat dari $78 \%$ menjadi $84,33 \%$. 
Hasil belajar siswa sebelum menggunakan metode inkuiri diperoleh nilai rata-rata mencapai 65,7, setelah menggunakan metode inkuiri meningkat menjadi 80,6.

Proses pembelajaran tematik yang dirancang sesuai sintak Inquiry learning dengan pendekatan saintifik mata pelajaran IPA pada pembelajaran energi dan perubahannya siswa kelas IV SD Negeri Kwayuhan, menjadi effektif. Siswa lebih aktif selama pembelajaran, siswa lebih mudah melakukan transfer knowledge, siswa cenderung berfikir kritis, dan mudah memecahkan masalah (Problim Solving). Keuntasan hasil belajar meningkat sebesar 35,7 \% dari $50 \%$ menjadi $85,5 \%$ dan hasil belajar rata-rata siswa meningkat 7,2 poin dari $71,8 \%$ menjadi 79.

Model pembelajaran Inquiry Learning didesain untuk dapat diterapkan dalam pembelajaran tematik terpadu dengan sintak-sintak pada Tabel 3 sebagai berikut.

Tabel 3. Rencana Sintak Model Inquiry Learning

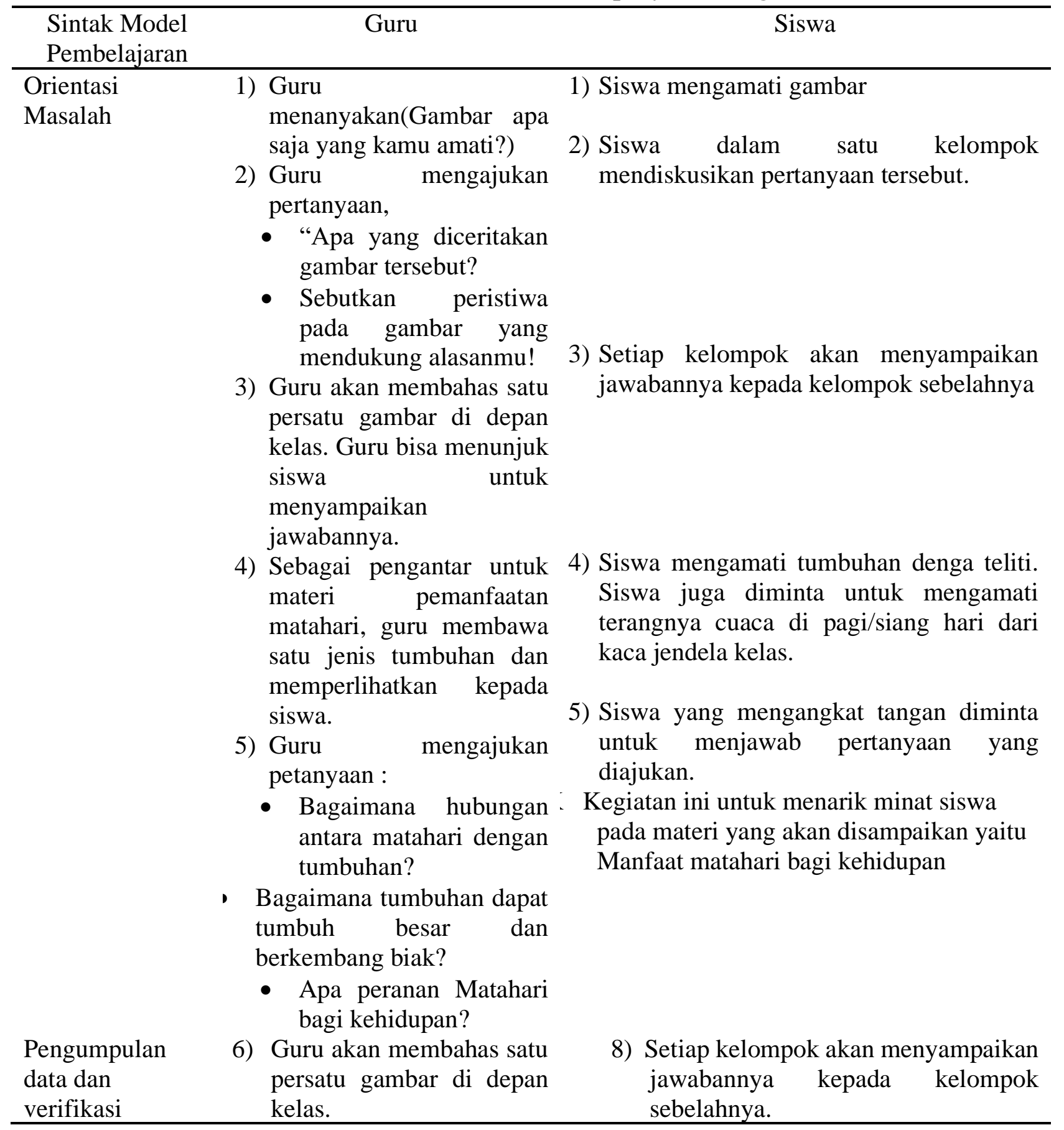


7) Guru bisa menunjuk siswa untuk menyampaikan jawabannya.

Pengumpulan data melalui eksperimen

Pengorganisasian dan Formulasie eksplanasi
13) Guru menyiapkan alat dan bahan untuk percobaan

14) Guru berkeliling ke setiap kelompok untuk memastikan siswa berperan aktif dan tertib menjalankan tugasnya.

17) Guru memberikan lembaran-lembaran kertas HVS sehingga siswa dapat leluasa menuangkan ideide tentang peta pikiran yang dapat dipajang sebagai sumber belajar bagi siswa lainnya.
9) Secara individu siswa akan menuliskan gagasan pokok dari gambar yang telah diamatinya. Siswa akan menukar jawabannya kepada teman sebelahnya. (Collaburation)

10) Siswa kemudian mengamati gambar tentang peran matahari bagi kehidupan di Bumi. Ingatkan siswa untuk mengamati dengan teliti setiap detail pada gambar tersebut.

11) Siswa menjawab pertanyaan berdasarkan gambar.

12) Siswa juga diminta untuk mengilustrasikan tentang manfaat lain matahari selain yang telah tertera pada gambar. (Creativity and Innovation)

15) Siswa melakukan percobaan untuk membuktikan penguapan zat cair oleh panas matahari, berdasarkan instruksi yang terdapat di buku.

16) Saat menunggu proses percobaan, siswa mengerjakan tugas membaca senyap teks pendek "Kisah Ali si Biji Energi" yang terdapat di buku.

18) Siswa kemudian menuliskan manfaat matahari bagi kehidupan di Bumi dalam bentuk peta pikiran

19) Siswa dibebaskan untuk membuat peta pikiran mereka dalam bentuk tulisan maupun gambar.

20) Berikut adalah contoh peta pikiran yang diharapkan dapat dimunculkan oleh siswa:

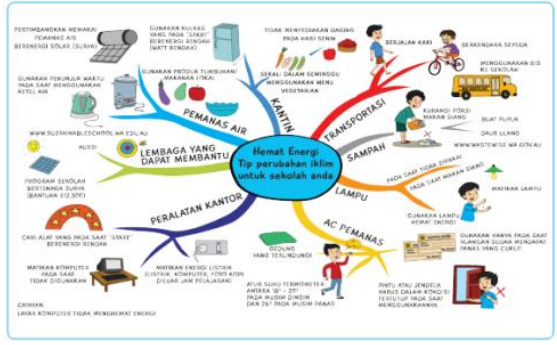

1) Siswa dalam kelompok kemudian melanjutkan pengamatan hasil percobaan tentang pengaruh panas matahari pada zat cair di Bumi.

2) Siswa menuliskan 4 pengaruh panas matahari pada objek benda berdasarkan hasil percobaan. 


\section{Berdiskusi}

3) Siswa menuliskan proses dan hasil percobaan dalam bentuk laporan.

1) Siswa mengamati gambar jagung bakar yang terdapat di buku.

2) Siswa secara berpasangan dengan teman di sebelah kemudian mendiskusikan pertanyaan bacaan terkait materi tentang ketersediaan sumber daya alam.

(Critical Thinkig and Problem Formulation)

Membaca(Tugas Mandiri) :

1) Siswa membaca senyap teks tentang jenis-jenis sumber daya alam.

2) Siswa menjawab pertanyaan berdasarkan teks, dan menuliskannya di buku.

3) Siswa secara berpasangan mendiskusikan jawaban mereka.

4) Siswa menjawab pertanyaan berdasarkan bacaan, dan menuliskannya di buku.

5) Siswa mendiskusikan jawaban bersama teman.

6) Siswa kembali diminta untuk menggambarkan penggunaan salah satu sumber daya alam yang patut dicontoh. Gambar mereka harus memuat kegiatan ekonomi yang menggunakan salah satu sumber daya alam dan usaha menjaga keberadaannya.

7) Siswa saling menyampaikan gambar mereka kepada seorang teman untuk diberikan masukan.

8) Siswa kemudian menjelaskan gambar mereka dalam bentuk tulisan.

9) Tulisan yang dibuat harus memuat Sumber daya alam yang dipilih dan yang diperjualbelikan, serta contohcontoh kegiatan untuk menjaga kelestariannya.

\section{KESIMPULAN}

Berdasarkan pemaparan di atas dapat disimpulkan bahwa pembelajaran tematik dengan model pembelajaran Inquiry Learning layak dijadikan praktik baik pembelajaran berorientasi HOTS karena dapat meningkatkan kemampuan siswa dalam melakukan transfer pengetahuan, berpikir kritis, dan pemecahan masalah. Dengan penyusunan rencana pelaksanaan pembelajaran (RPP) secara sistematis dan cermat, pembelajaran tematik dengan model 
pembelajaran Inquiry Learning yang dilaksanakan tidak sekadar berorientasi HOTS, tetapi juga mengintegrasikan PPK, literasi, dan kecakapan abad 21.

\section{DAFTAR PUSTAKA}

Abdullah Sani, Ridwan. (2015). Pembelajaran Saintifik untuk Implementasi Kurikulum 2013. Bandung: Bumi Aksara.

Al-Tabani, Trianto Ibnu Badar. (2014). Mendesain Model Pembelajaran Inovatif, Progresif, dan Kontekstual: Konsep, Landasan, dan Implementasinya pada Kurikulum 2013. Jakarta: Kencana.

Aprilia, Achyar Afifatul. (2009). Ilmu Pengetahuan Alam untuk SD dan MI Kelas 4. Jakarta: Pusat Perbukuan, Departemen Pendidikan Nasional.

Aprianoto, Ruli Diyan. (2015). Penerapan Model Inkuiri untuk Meningkatkan Pembelajaran IPA di Kelas $\mathrm{V}$ pada Materi Magnet SDN Bandungrejosari 1 Kota Malang.http://library.um.ac.id/ptk/index.php?mod=detail\&id=70785, diakses pada tanggal 19 Agustus 2021 pukul 05.30

Banawi, Asmin. (2019). Implementasi Pendekatan Saintifik Pada Sintaks Discovery/Inquiry Learning, Based Learning, Project Based Learning. Biosel: Biology Science and Education,

Daryanto. (2014). Pendekatan Pembelajaran Saintifik Kurikulum 2013. Yogyakarta: Penerbit Gava Media.

Kementerian Pendidikan dan Kebudayaan. (2013). Buku Guru Tema 2 Kelas 4 dan Buku Siswa Tema 2 Kelas 4 (Buku Tematik Terpadu Kurikulum 2013). Jakarta: Author.

Lubis, MA (2019). Pembelajaran Tematik di SD/MI: Pengembangan Kurikulum 2013/Maulana Arafat Lubis editor, Alviana C. Yogyakarta : Samudra Biru. ISBN: 978-602-5610-11-6

Salinan Lampiran Peraturan Menteri Pendidikan dan Kebudayaan Republik Indonesia Nomor 103 Tahun 2014 Tentang Pembelajaran Pada Pendidikan Dasar dan Pendidikan Menengah, diakses dari https://pgsd.uad.ac.id/wp-content/uploads/lampiranpermendikbud-no-103-tahun-2014.pdf. tanggal 26 Agustus 2021pukul 09.51

SE Arlita, A Zazili. (2020). Program Peningkatan Kopetensi Pembelajaran dan Penerapan Model Pembelajaran Berorientasi Hots.https://jurnal.univpgripalembang.ac.id/index.php/Prosidingpps/article/download/3898/3636, diakses pada tanggal 19 Agustus 2021 pukul 05.35

Sudrajat, Akhmad. (2012). Strategi Pembelajaran Inkuiri. https://id.scribd.com/doc/96321935/Strategi-Pembelajaran-Inkuiri-Akhmad-Sudrajat, diakses pada tanggal 20 Agustus 2021 pukul 19.37

Suja, I Wayan. (2019). Pendekatan Saintifik dalam Pembelajaran. http://lpppm.undiksha.ac.id/wp-content/uploads/2021/03/Pendekatan-Saintifik-dalamPembelajaran-1.pdf, diakses pada tanggal 19 Agustus 2021 pukul 5.32 